University of Michigan Law School

University of Michigan Law School Scholarship Repository

Other Publications

Faculty Scholarship

2013

\title{
Toward A Sustainable Future: An Environmental Agenda for the Second Term of the Obama Administration
}

David M. Uhlmann

University of Michigan Law School, duhlmann@umich.edu

Available at: https://repository.law.umich.edu/other/75

Follow this and additional works at: https://repository.law.umich.edu/other

Part of the Administrative Law Commons, Energy and Utilities Law Commons, Environmental Law Commons, and the President/Executive Department Commons

\section{Recommended Citation}

Toward a Sustainable Future: An Environmental Agenda for the Second Term of the Obama Administration. American Constitutional Society for Law and Policy Issue Brief Series, January 2013.

This Report is brought to you for free and open access by the Faculty Scholarship at University of Michigan Law School Scholarship Repository. It has been accepted for inclusion in Other Publications by an authorized administrator of University of Michigan Law School Scholarship Repository. For more information, please contact mlaw.repository@umich.edu. 
IV

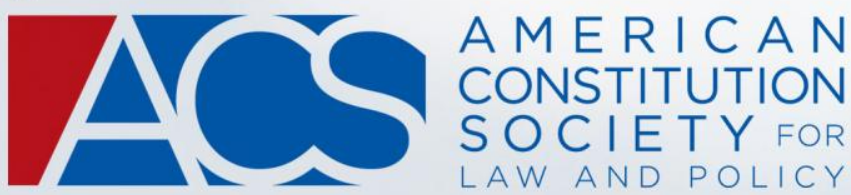

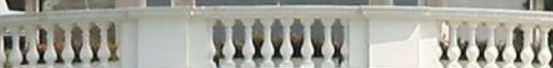

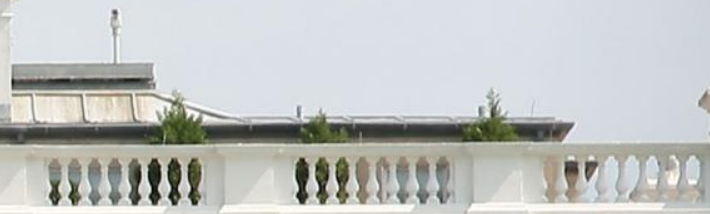

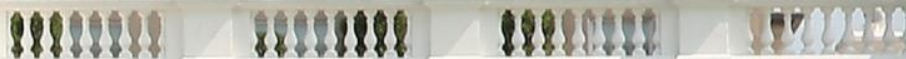

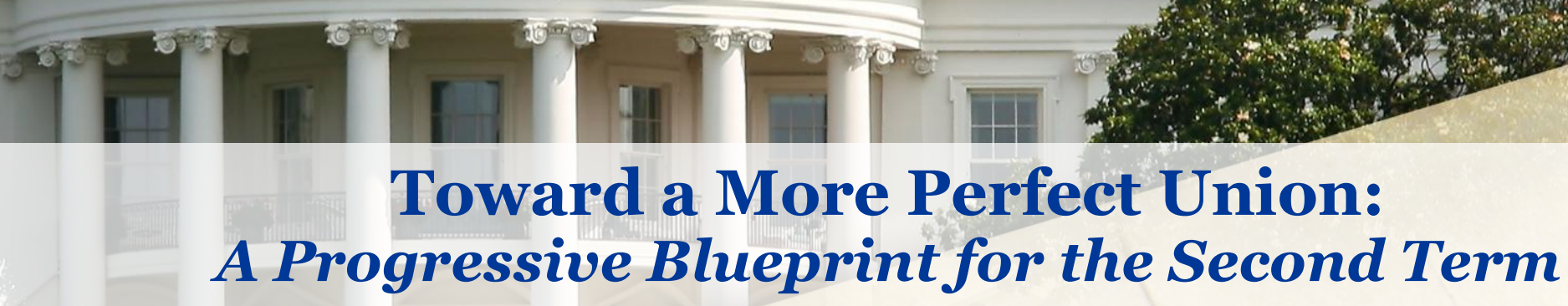

\section{January 2013}

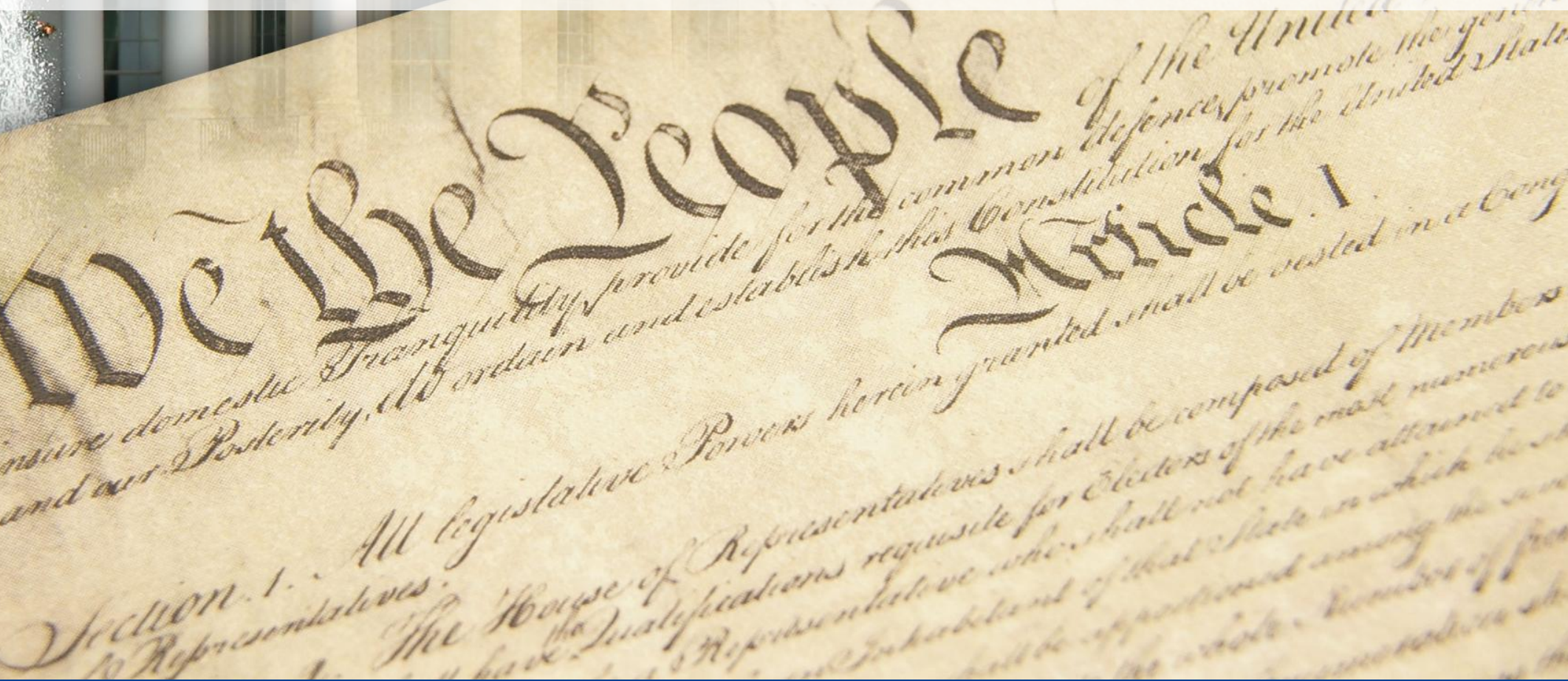

"Toward a Sustainable Future: An Environmental Agenda for the Second Term of the Obama Administration" 


\section{Toward a More Perfect Union: A Progressive Blueprint for the Second Term}

"Toward a More Perfect Union: A Progressive Blueprint for the Second Term" is a series of ACS Issue Briefs offering ideas and proposals that we hope the administration will consider in its second term to advance a vision consistent with the progressive themes President Obama raised in his second Inaugural Address. The series should also be useful for those in and outside the ACS network - to help inform and spark discussion and debate on an array of pressing public policy concerns. The series covers a wide range of issue areas, including immigration reform, campaign finance, climate change, criminal justice reform, and judicial nominations.

All expressions of opinion are those of the author or authors.

The American Constitution Society (ACS) takes no position on specific legal or policy initiatives. 


\title{
Toward a Sustainable Future: An Environmental Agenda for the Second Term of the Obama Administration
}

\author{
David M. Uhlmann* \\ We will respond to the threat of climate change, knowing that the failure \\ to do so would betray our children and future generations.
}

--President Barack Obama, January 21, 2013

Much was at stake in the Presidential election of 2012, which was marked by heated debate over the trajectory of the economy, the expiration of the Bush tax cuts, and the fate of the President's health care plan. The candidates disagreed about nearly every issue from foreign policy and the war on terror to a woman's right to choose and samesex marriage. Lost amid the din and never mentioned in the Presidential debates or most of the campaign speeches was another divisive topic: how our environmental laws and policies should address global climate change and chart a sustainable future for the United States and the world.

Yet the environment was on the ballot during the 2012 election, despite its absence from the national debate. The President's efforts to address climate change, promote renewable energy, and provide stronger environmental protection would have been reversed or curtailed if he had lost the election. The environment also arguably influenced the outcome of the 2012 election when Hurricane Sandy struck and gave the President the opportunity to show bi-partisan leadership. It has become almost a cliché to say that no one storm can be attributed to climate change, but Hurricane Sandy underscored both our collective yearning to move beyond partisanship and the moral imperative of decisive steps to address climate change.

The President should make climate change a center-piece of his second term agenda. No single issue will have a greater long-term effect on our ability to thrive as a nation, as the ravages of record heat and killer storms made clear throughout 2012. The scientific verdict was reached years ago: our climate is changing, we are the cause, and

\footnotetext{
* Jeffrey F. Liss Professor from Practice and Director of the Environmental Law and Policy Program at the University of Michigan Law School. I would like to thank Ben Kobren for his outstanding research assistance, Virginia Murphy for comments on drafts of the article, and Dipal Shah and the American Constitution Society for the invitation to publish my views in the ACS Briefing Series for the Second Term of the Obama Administration.
} 
the economic costs of continued inaction will dwarf the dislocation and hardship of the Great Recession. ${ }^{1}$

Despite the significance of climate change and the substantial near-term and longterm benefits of mitigation efforts, we have not reached anything approaching a national consensus about the need for action. ${ }^{2}$ To be fair, it is difficult for many Americans to focus on a crisis that will not produce its worst effects for decades when they are worried about immediate challenges like job security or making mortgage payments. Complicating matters, there invariably will be economic winners and losers in the shift to a green economy; it is understandable that those who fare better under the status quo may continue to resist action to address climate change. ${ }^{3}$

The difficult politics of climate change underscore the need for Presidential leadership. As he did in his Second Inaugural Address, the President should reframe the climate change imperative with an emphasis on our obligations to future generations. Just as we must approach budget deficits with an eye toward crafting policies that will ensure long-term financial security, we should approach climate change with an emphasis on promoting a sustainable future.

An environmental agenda for the second term of the Obama administration therefore should be a sustainability agenda, which recognizes what local communities and business leaders discovered years ago about the need for balance in how we approach our role as stewards of the environment. ${ }^{4}$ Our communities and businesses will thrive if we pursue policies that promote economic growth and environmental protection, instead of viewing them as competing objectives. ${ }^{5}$ We can meet our obligations to future generations if we treat our planet, not as an infinite resource, but as a precious habitat that sustains life. ${ }^{6}$

This Issue Brief will outline the core elements of an agenda for a sustainable future, which begins with climate change mitigation but should not end there. It is not

${ }^{1}$ See, e.g., R. K. Pachauri, Statement: Intergovernmental Panel On Climate Change (IPCC) at the Eighteenth Conference of The Parties Doha (Nov. 28, 2012).

2 Poll: More Say There Is Solid Evidence of Global Warming, Pew Research Center (Oct. 15, 2012), http://www.people-press.org/2012/10/15/more-say-there-is-solid-evidence-of-global-warming/.

${ }^{3}$ See J. B. Ruhl, The Political Economy of Climate Change Winners, 97 MinN. L. REv. 207 (2012).

${ }^{4}$ See, e.g., U.S. Dep't of Agriculture, Farmers Market Growth: 1994-2012, (Aug. 3, 2012), http://www. ams.usda.gov/AMSv1.0/ams.fetchTemplateData.do?template=TemplateS\&leftNav=WholesaleandFarmers Markets\&page $=$ WFMFarmersMarketGrowth\&description=Farmers\%20Market\%20Growth\&acct=frmrdir mkt. See also, John Elkington, Cannibals with Forks: The Triple Bottom Line of $21^{\text {ST }}$ Century BUSINESS (1999).

5 See, e.g., Herman E. Daly \& John B. Cobb, Jr., For The Common Good: Redirecting The ECONOMY TOWARD COMMUNITY, THE ENVIRONMENT, AND A SuSTAINABle Future (2d ed. 1994).

${ }^{6}$ See David M. Uhlmann, The Quest for a Sustainable Future and the Dawn of a New Journal at Michigan Law, 1 Mich. J. ENVTL \& ADMIN. L. 1 (2012). 
possible to address all issues that should be part of a sustainability agenda in an article of this length, but a sustainability agenda should promote the following:

- $\quad$ Climate change mitigation efforts that include a market-based price signal such as a carbon tax and more traditional regulatory measures under the Clean Air Act;

- Continued participation in multi-lateral negotiations concerning greenhouse gas emissions, deforestation, and adaptation efforts in the developing world;

- Support for renewable energy and the green jobs that it will provide, including a national renewable portfolio standard and tax credits for renewable energy;

- Infrastructure investments that include a smart grid for electricity, storm barriers in communities at risk from hurricanes, and upgrades to waste treatment plants;

- $\quad$ Revised national ambient air quality standards under the Clean Air Act and new regulations clarifying the jurisdictional reach of the Clean Water Act; and

- Regulations to ensure that hydraulic fracturing or "fracking" does not create unacceptable public health and environmental risks.

The President would be able to accomplish far more in each of these sustainability efforts with support from Congress-particularly with regard to climate change-but even without Congressional action, his administration should continue to use existing laws to chart a path toward a sustainable future for the United States and the world.

\section{The Moral Imperative of Climate Change Mitigation}

The United States finally took its first steps to address climate change in the first term of the Obama administration. The Environmental Protection Agency (EPA) determined that greenhouse gas emissions are endangering public health and the environment ${ }^{7}$ and promulgated regulations to (1) address greenhouse gas emissions from automobiles; ${ }^{8}$ (2) inventory sources of greenhouse gases $;^{9}$ and (3) limit emissions from

\footnotetext{
${ }^{7}$ Endangerment and Cause or Contribute Findings for Greenhouse Gases Under Section 202(a) of the Clean Air Act, 74 F.R. 66496 (Dec. 15, 2009).

${ }^{8}$ Envtl. Protection Agency, Regulatory Announcement, EPA and NHTSA Set Standards to Reduce Greenhouse Gases AND Improve Fuel ECONOMy for Model Years 2017-2025 Cars AND Light TRUCKS (August 28, 2012), available at http://www.epa.gov/otaq/climate/documents/420f12051. pdf.
} 
newly built large stationary sources such as factories and refineries. ${ }^{10}$ The United States also re-engaged international efforts to address climate change. ${ }^{11}$ President Obama negotiated the final terms of the Copenhagen accord, ${ }^{12}$ which included commitments to reduce emissions by all major emitters, landmark agreements on financial assistance, and technology assistance to help developing countries adapt to the effects of climate change and promote sustainability efforts. Yet overall the President's first term disappointed environmentalists, because Congress failed to enact comprehensive greenhouse gas legislation even as climate change projections worsened.

\section{A. The Need for Presidential Leadership on Climate Change}

For better results to occur in the second term, particularly given Republican opposition to climate change legislation, the President will need to make climate change action a top priority. The President must engage the public far more than any President has ever done regarding climate change and on the imperative of acting now to prevent catastrophic effects.

The argument for bold efforts to address climate change has never been more compelling. NASA reported in 2011 that nine of the ten hottest years on record have occurred since 2000. ${ }^{13}$ During 2012, the United States experienced the hottest temperatures ever in the lower 48, a devastating drought that will hamper agriculture in the United States for years, and extreme weather events culminating in Hurricane Sandy that caused billions of dollars in losses. ${ }^{14}$

Yet climate scientists predict that the perils of 2012 are just a warm-up act: if we fail to limit greenhouse gas emissions, searing heat, widespread drought, destructive storms, and massive flooding will become commonplace. ${ }^{15}$ Most climate scientists also

\footnotetext{
${ }^{9}$ Mandatory Reporting of Greenhouse Gases, 74 F.R. 56260 (Oct. 30, 2009).

${ }^{10}$ Prevention of Significant Deterioration and Title V Greenhouse Gas Tailoring Rule, 75 F.R. 31514 (Jun. 3, 2010).

${ }^{11}$ David Turnball, Todd Stern's speech cheers delegates at Bonn climate talks, GRIST (Mar. 31, 2009), http://grist.org/article/2009-03-30-todd-sterns-speech-cheers1/.

${ }^{12}$ Darren Samuelsohn, Obama Negotiates 'Copenhagen Accord' With Senate Climate Fight in Mind, N.Y. TIMES, Dec. 21, 2009, http://www.nytimes.com/cwire/2009/12/21/21climatewire-obama-negotiatescopenhagen-accord-with-senat-6121.html?pagewanted=all.

${ }^{13}$ Press Release, Nat'l Aeronautics and Space Admin., No. 12-020, NASA Finds 2011 Ninth-Warmest Year on Record, (Jan. 12, 2012).

${ }^{14}$ Justin Gillis, Not Even Close: 2012 Was Hottest Ever in U.S., N.Y. TIMES, Jan. 8, 2013 at A1; Carey Gillam, U.S. Drought Expands, Concerns Mount About Wheat and Rivers, ReuTERS, Dec. 6, 2012, http://www.reuters.com/article/2012/12/06/usa-drought-idUSL1E8N67SP20121206; EQECAT, POSTLANDFALL LOSS ESTIMATES FOR SUPERSTORM SANDY (Nov. 1, 2012), http://www.eqecat.com/catwatch/ post-landfall-loss-estimates-superstorm-sandy-released-2012-11-01/.

${ }^{15}$ Seth Borenstein, Intergovernmental Panel On Climate Change: Get Ready For Extreme Weather, THE HuFFINGTON POST (Nov. 11, 2011), http://www.huffingtonpost.com/2011/11/18/intergovernmental-panelclimate-change-weather_n_1101270.html.
} 
expect oceans to rise later this century, which could make parts of major east coast cities, including Miami, New York, and Boston, uninhabitable. ${ }^{16}$ The Pentagon has warned that climate change could threaten American interests abroad, since the worst effects could occur in highly-populated areas of Africa, Asia, and the Middle East, with resulting political instability and mass migrations. ${ }^{17}$

Climate change will be a legacy issue for President Obama-either because he helped chart a course toward a sustainable future or because America failed to act while it was still possible to prevent catastrophic climate change. For a President who understands the merits of the science and the perils of inaction, there is no choice about how to proceed. The President should make climate change a centerpiece of his 2013 State of the Union Address and present a comprehensive plan to meet the climate change challenge in a separate address to the Nation. The President also should be prepared to take his case directly to the American people, with campaign-style events to generate support for his proposals, lest his opponents sow doubt about the need for strong action by again promoting the work of climate change skeptics. ${ }^{18}$

\section{B. A Carbon Tax and the Federal Budget Crisis}

The best opportunity for legislative action to address climate change may be now, at a time of budget deficits and soaring debt. The President should advocate for a carbon tax as one of the ways to raise revenue to address the federal budget deficit. A recent Massachusetts Institute of Technology study found that a relatively modest carbon tax of $\$ 20$ per ton imposed on the carbon content of all fossil fuels produced in the United States or imported from abroad would generate $\$ 1.5$ trillion in tax revenue over a tenyear period. ${ }^{19}$ Some of the revenue would need to be reserved to address the regressive effects of a carbon tax and the degree to which its effects might be felt disproportionately by regions that rely on coal and other carbon-rich forms of energy. But the remaining revenue could be used to help generate funds to reduce the federal budget deficit, without relying exclusively on income taxes or discretionary spending cuts. ${ }^{20}$

\footnotetext{
${ }^{16}$ Benjamin Strauss and Robert Kopp, Op-ed, Rising Seas, Vanishing Coastlines, N.Y. TimES, Nov. 25, 2012 at SR6.

${ }^{17}$ U.S. DeP'T of Defense, Quadrennial Defense Review Report, at 84 (Feb. 2010), available at http://www.defense.gov/qdr/images/QDR_as_of_12Feb10_1000.pdf.

${ }^{18}$ Ben Johnson, Mitt Romney Goes Climate Change Skeptic, Slate, Oct. 29, 2011, http://slatest.slate. com/posts/2011/10/29/mitt_romney_flip_flops_on_climate_change_global_warming.html.

${ }_{19}$ Sebastian Rausch and John Reilly, Carbon Tax Revenue and the Budget Deficit: A Win-Win-Win Solution? (MIT Joint Program on the Science and Policy of Global Change, Aug. 2012), available at http://globalchange.mit.edu/files/document/MITJPSPGC_Rpt228.pdf. See also Mark Muro and Jonathan Rothwell, Institute a Modest Carbon Tax to Reduce Carbon Emissions, Finance Clean Energy Technology Development, Cut Taxes, and Reduce the Deficit, (The Brookings Institute, Nov. 2012), http://www. brookings.edu/ /media/research/files/papers/2012/11/13\%20federalism/13\%20carbon\%20tax.pdf.

${ }^{20}$ See Thomas Friedman, Op-ed, The Market and Mother Nature, N.Y. TIMES, Jan. 8, 2013, at A21.
} 
From an economic standpoint, a carbon tax would provide the price signal that has long been advocated by economists as the best way to address the market failure that is greenhouse gas emissions. Greenhouse gas emissions are a classic externality. Facilities that emit greenhouse gases do so at no cost to their bottom lines but at an enormous cost to society. Imposition of a carbon tax would help ensure that the costs associated with carbon dioxide emissions are imposed on the facilities that emit carbon dioxide. $^{21}$

From a climate change standpoint, the benefits of a carbon tax extend beyond revenue and price signals. Since greenhouse gas emissions are the leading anthropogenic cause of climate change, reducing emissions is at the heart of any solution to climate change. $^{22}$ A carbon tax would reduce greenhouse gas emissions in the United States, by making carbon-rich energy sources more expensive and thus creating incentives for the use of renewable energy, such as wind and solar, which do not contribute to climate change.

Of course, the merits of market based approaches to climate change have been known since at least 2008 when both major party candidates supported climate change mitigation. $^{23}$ Now, with the political climate worse than it was in 2008, it is questionable whether a carbon tax would fare any better than cap and trade legislation, which passed the House of Representatives in 2010 only to die in the Senate. ${ }^{24}$ But President Obama did not take his case directly to the American people in 2010, when his energy was focused on health care and financial reform. His leadership combined with the wake-up call of Hurricane Sandy could be game-changers for a carbon tax, which enjoys broad support from economists across the political spectrum. ${ }^{25}$

\section{Climate Change Mitigation Efforts Without Congress}

Even without climate change legislation, the President can provide leadership on climate change mitigation by continuing or expanding efforts begun during his first term:

\footnotetext{
${ }^{21}$ See Reuven Avi-Yonah and David M. Uhlmann, Combatting Global Climate Change: Why a Carbon Tax Is a Better Response to Global Warming Than Cap and Trade, 28 STAN. ENVT'L. L. J.30 (2009).

${ }^{22}$ InT'L PANel on Climate Change, IPCC Fourth Assessment RePORT 2.1 (2007), http://www.ipcc.ch/ pdf/special-reports/srren/SRREN_Full_Report.pdf; JOS G.J. OLIVIER, GREET JANSSENS-MAENHOUT, and Jeroen A.H.W. Peters, Trends in Global CO2 Emissions 6 (Emission Database for Global Atmospheric Research, 2012), http://edgar.jrc.ec.europa.eu/CO2REPORT2012.pdf.

${ }^{23}$ Andrew C. Revkin, On Global Warming, McCain and Obama Agree: Urgent Action is Needed, N.Y. TiMES, Oct.19, 2008 at A2.

${ }^{24}$ Tom Dickenson, Climate Bill, R.I.P., Rolling Stone, July 21, 2010, http://www.rollingstone.com/ politics/news/climate-bill-r-i-p-20100721.

${ }^{25}$ Steve Hargraeves, Carbon Tax Gets Unusual Support, CNN MoNEy (Aug. 2, 2012), http://money.cnn. com/2012/07/30/news/economy/carbon-tax/index.htm.
} 
- $\quad$ The Justice Department should vigorously defend EPA's endangerment finding and the Agency's efforts to regulate greenhouse gas emissions.

- $\quad$ EPA should promulgate new regulations under the Clean Air Act to reduce greenhouse gas emissions from stationary sources, including power plants.

- The Council on Environmental Quality should require climate change effects to be included in environmental impact statements and environmental assessments conducted under the National Environmental Policy Act.

- $\quad$ The Department of Energy should promote wider compliance with its Energy Star program and increased energy efficiency standards, which offer the dual benefits of reduced greenhouse gas emissions and lower energy costs for consumers.

- $\quad$ The General Services Administration should ensure that all new building construction by the federal government meets Leadership in Energy and Environmental Design (LEED) requirements for green buildings and that renovations of existing buildings utilize best practices for sustainability.

- The Department of Transportation should promote sustainable transportation programs including high-speed rail to connect regional economic centers, expanded mass transit, and new technologies to reduce motor vehicle emissions.

All of these efforts can occur under existing laws, either by Executive Order or promulgation of new regulations, without the need for Congressional action.

\section{International Efforts to Address Climate Change}

The United States should continue to engage international efforts to establish targets for greenhouse gas emission reductions, technology cooperation to promote renewable energy, and measures to prevent deforestation. Although talks during 2012 in Doha, Qatar failed to produce agreement on a replacement for the Kyoto Protocol or further steps to curb deforestation, ${ }^{26}$ the United States and other developed countries are beginning to meet the commitments made in Copenhagen to aid developing countries.

\footnotetext{
${ }^{26}$ John M. Broder, Climate Talks Yield Commitment to Ambitious, but Unclear, Actions, N.Y. Times, Dec. 8, 2012, at A13.
} 
The United States already has provided $\$ 7.5$ billion, its share of around $\$ 30$ billion of fast start funding pledged in Copenhagen. ${ }^{27}$

In addition, the United States is playing a leading role in international partnerships such as the Climate and Clean Air Coalition and the Global Alliance for Clean Cookstoves, which offer substantial near-term benefits by reducing short lived climate pollutants such as methane, black carbon, and HFCs. The Climate and Clean Air Coalition, announced by Secretary of State Hillary Clinton in 2012, focuses on reducing climate pollutants such as methane, black carbon, and HFCs, which have short lifetimes in the atmosphere, but significant warming influences. ${ }^{28}$ The Global Alliance for Clean Cookstoves is a public-private partnership to support the adoption of clean cookstoves in 100 million households by 2020 , which also would reduce short-lived climate pollutants and deforestation rates. ${ }^{29}$

Nonetheless, greenhouse gas emissions continue to rise, and insufficient progress has been made toward meeting emissions reduction targets set forth in the Copenhagen accord. ${ }^{30}$ The United States therefore should intensify its efforts in the multilateral Major Economies Forum on Energy and Climate. The forum brings together the world's 17 largest emitters in an effort to facilitate agreement at the United Nations conventions. ${ }^{31}$ If the biggest emitters agree about commitments, it will improve the chances that all 192 parties can reach agreement or at least ensure multi-lateral agreements for substantial reductions in greenhouse gas emissions.

\section{Promoting Renewable Energy and Investing in America}

Any effort to address climate change and promote a sustainable future hinges on energy policy, since the leading source of carbon dioxide emissions is from the combustion of fossil fuels to generate electricity. ${ }^{32}$ A shift from fossil fuels to renewable

27 Developed Country Fast-Start Climate Finance Pledges: A Summary of Self-Reported INFORMATION, WORLD RESOURCES INSTITUTE (Nov. 26, 2012), http://pdf.wri.org/climate_finance_ pledges_2012-11-26.pdf.

${ }_{28}$ Elisabeth Rosenthal, Burning Fuel Particles Do More Damage to Climate Than Thought, Study Says, N.Y. Times, Jan. 15, 2013 at A9; Climate And Clean Air CoAlition to Reduce Short-Lived Climate POLLUTANTS http://www.unep.org/ccac/ShortLivedClimatePollutants/tabid/101650/Default.aspx (last visited Jan. 5, 2013).

29 The Alliance has grown to include 400 partners and 36 countries with commitments of hundreds of millions of dollars, which will improve the environment as well as the health and economic well-being of three billion people. See Global Alliance For Clean CoOKStoves http://www.cleancookstoves.org/ (last visited Jan. 5, 2013).

${ }^{30}$ Justin Gillis and John M. Broder, With Carbon Dioxide Emissions at Record High, Worries on How to Slow Warming, N.Y. TIMES, December 2, 2012, at A6.

${ }^{31}$ MAJOR ECONOMIES FORUM, http://www.majoreconomiesforum.org/ (last visited Jan. 5, 2013).

32 The combustion of fossil fuels for electricity is the largest source of carbon dioxide emissions in the United States accounting for 40 percent of all emissions. Transportation is second, accounting for 31 
forms of energy, which do not produce greenhouse gas emissions, must be at the heart of climate change mitigation efforts. We also stand to reap economic benefits from the manufacturing of renewable energy technology, as it becomes an increasingly significant part of the global economy. ${ }^{33}$

The imperative of a shift to renewable energy reflects other realities too. Our reliance on dwindling reserves of fossil fuels requires increasingly risky behavior to meet our energy needs, such as deep water drilling in the Gulf of Mexico and proposals to drill for oil in the Alaska National Wildlife Refuge, as well as practices like mountaintop mining removal to provide more efficient access to coal reserves. In addition, the burning of fossil fuels has substantial environmental impacts beyond climate change, resulting in the release of mercury and air toxins that harm public health and cause animal mortality. ${ }^{34}$ For these reasons, the President's efforts to promote renewable energy are an essential part of any sustainability agenda, as are the infrastructure investments needed to supply electricity, adapt to climate change that already is occurring, and prevent pollution from aging wastewater treatment plants across America.

\section{A. Renewable Portfolio Standards}

Renewable energy is increasing its market share of total energy production. In 2011, renewables provided 12.7 percent of total domestic electricity, up from 10.2 percent in 2010, and 9.3 percent in $2009 .{ }^{35}$ A recent study by the International Energy Agency reported global renewable energy is expected to grow by 60 percent between 2011 and 2017. ${ }^{36}$ Moreover, 2011 saw the largest investment in renewable technology to date $-\$ 51$ billion in the United States and $\$ 257$ billion worldwide excluding hydropower. $^{37}$

Many states recognize the benefits of renewable energy and have established renewable energy portfolio standards (RPS) to promote its growth. As of January 2012, 30 States and the District of Columbia had an enforceable RPS or other type of mandated

percent. U.S. ENVtl Protection AGEncy, GreEnhouse Gas EMissions, http://www.epa.gov/ climatechange/ghgemissions/gases/co2.html (last visited Jan. 5, 2013).

33 See Robert Pollin, James Heintz, and Heidi Garrett-Peltier, The Economic Benefits of Investing in Clean Energy, (Center for American Progress, June 2009), available at http://www.americanprogress.org/wpcontent/uploads/issues/2009/06/pdf/peri_report.pdf.

${ }^{34}$ U.S. Envt'L Protection Agency, Mercury AND AIR Toxins, http://www.epa.gov/mats/basic.html (last visited Jan. 5, 2013).

35 Press Release, UNEP and Renewable Energy Policy Network for the $21^{\text {st }}$ Century, Global Renewable Energy Investment Powers to Record \$257 Billion (June 11, 2012), available at http://fs-unepcentre.org/sites/default/files/media/gsr2012_press_release_short_english.pdf.

${ }^{36}$ Press Release, International Energy Agency, Medium-Term Renewable Energy Market Report 2012

(July 5, 2012), https://www.iea.org/newsroomandevents/pressreleases/2012/july/name,28200,en.html.

${ }^{37}$ Id. 
renewable capacity policy. ${ }^{38}$ A minimum requirement for renewable energy stimulates technological development and fosters a competitive energy market.

The President should expand his support for renewable energy by including a federal renewable energy standard in a federal Clean Energy Standard. In the last Congress, legislation was introduced that would meet the President's goal to have clean energy provide 80 percent of electricity by $2035 .^{39}$ The benefit of a Clean Energy Standard is that it allows new energy sources to compete against one another to become the most efficient and cost effective solution. The challenge of a Clean Energy Standard is that the definition of clean energy is not limited to renewables such as wind, solar, biomass, and hydropower; it also includes nuclear power, natural gas, and coal with carbon capture utilization and sequestration. ${ }^{40}$ Natural gas has a role in our energy future but it produces greenhouse gas emissions, so its development should not crowd out renewable energy technology both for use in the United States and markets abroad. ${ }^{41}$

President Obama therefore should advocate for a hybrid clean energy and renewable portfolio standard, which maintains the overall goal that clean energy account for 80 percent of our electricity by 2035 but also requires that 25 percent of electricity will come from renewables in that same time period. Individual states, as many have already done, could set higher goals, but a federal RPS would ensure a domestic market for renewable technology - and with it the economic opportunity for American companies to compete both at home and abroad in developing the renewable energy technology and manufacturing capacity for the future.

\section{B. Long-Term Tax Credits for Renewable Energy}

The fiscal cliff negotiations produced a one-year extension of tax credits for renewable energy, but to sustain investment and maintain growth in renewable energy, the sector must have the ability to compete in a fair market place. Federal investment incentives such as the $\$ 2.4$ billion for Clean Renewable Energy Bonds included in The American Recovery and Reinvestment Act of 2009 and other tax incentives have enabled the development of renewable energy technology and begun to bring down the cost of renewable energy so that it may become more cost-effective. Those programs must continue in the President's second term.

\footnotetext{
38 U.S. EnERgy Information Administration, Most States Have Renewable Portfolio STANDARDS, http://www.eia.gov/todayinenergy/detail.cfm?id=4850 (last visited Jan. 5, 2013).

${ }^{39}$ Timothy Gardner, Obama sets 2035 clean electricity target, REUTERS, Jan. 25, 2011, http://www.reuters. com/article/2011/01/26/us-obama-speech-energy-idUSTRE70O50V20110126.

${ }^{40}$ Bill Chameides, Is There a Clean Energy Standard in Our Future?, HufFington Post (May 17, 2012), http://www.huffingtonpost.com/bill-chameides/is-there-a-clean-energy-s_b_1525624.html.

${ }^{41}$ See Section III (C), supra, for more details on the opportunities and challenges presented by fracking.
} 
Uncertainty about the availability of tax credits for renewable energy jeopardizes future capital investments. When the Production Tax Credit for renewable energy was scheduled to expire at the end of 2012, investors became reluctant to continue investing in wind projects, which hindered growth of a key renewable energy resource. ${ }^{42}$ The same result will occur in the months ahead, if the Production Tax Credit remains scheduled to lapse at year-end.

It makes no sense to continue tax credits for the oil and gas industry indefinitely, while the renewable energy industry lurches from year-to-year with uncertainty about its favorable tax status. We should end the Oil Depletion Allowance and other measures that provide support to the multi-billion dollar fossil fuel industry that produces harmful greenhouse gas emissions. We should instead provide long-term support for the renewable energy industry, which will provide economic opportunities throughout the $21^{\text {st }}$ century and is critical to our energy independence and climate change mitigation. Doing so would ensure that renewables are supported at their inception just as the oil and gas industry was in its nascent stages. In the first fifteen years of subsidies to the oil and gas industry, subsidies accounted for one-half of one percent of the entire federal budget; ${ }^{43}$ subsidies to the renewable sector would never come close to that amount. ${ }^{44}$

\section{A Smart Grid for America}

Emissions reductions resulting from clean energy can only be realized when production is turned into consumer use. Unfortunately, our electric grid and transmission infrastructure is unable to be effective in a $21^{\text {st }}$ century clean energy economy. The current grid is unable to withstand increased demand and is incapable of properly delivering electricity from new clean energy sources to consumers. ${ }^{45}$ Investment in a smart grid is essential to a sustainable future.

Congress recognized the need to modernize the grid when it passed the Independence and Security Act of 2007. In addition, the 2009 American Recovery and Reinvestment Act included $\$ 4.5$ billion to modernize the grid; other public and private

\footnotetext{
${ }^{42}$ Production tax Credit for Renewable Energy, Union of Concerned Scientists, http://www. ucsusa.org/clean_energy/smart-energy-solutions/increase-renewables/production-tax-credit-for.html (last visited Jan. 5, 2013).

${ }^{43}$ Nancy Pfund and Ben Healey, What Would Jefferson Do? The Historical Role of Federal Subsidies in Shaping America's Energy Future (DBL Investors, Sept. 2011), http://www.dblinvestors.com/documents/ What-Would-Jefferson-Do-Final-Version.pdf.

${ }^{44}$ Steve Hargraeves, Energy subsidies total \$24 billion, most to renewables, CNN MONEY (Mar. 7, 2012), http://money.cnn.com/2012/03/07/news/economy/energy-subsidies/index.html (Renewable subsidies accounted for 16 billion dollars in federal support in 2011).

${ }^{45}$ Jeff Brady, An Aged Electric Grid Looks To A Brighter Future, NAT'L PUB. RADIO (NPR radio broadcast Apr. 27, 2009), transcript available at http://www.npr.org/templates/story/story.php?storyId=103327321.
} 
sources agreed to match that investment with $\$ 5.5$ billion. ${ }^{46}$ The investments to date are a good start, but far from what we need to create a modern electricity delivery system. A 2011 study by the Electric Power Research Institute (EPRI) projects the costs associated with revamping the grid at between $\$ 17$ billion to $\$ 24$ billion a year for the next 20 years. ${ }^{47}$ Despite those costs, the EPRI study projects that within the same period, a new smart grid will deliver $\$ 1.3$ trillion to $\$ 2$ trillion in benefits.

Updating the grid involves every aspect of the way electricity is transmitted to the consumer-from poles and transmission lines to household components and everything in between, including meters, storage, billing, and computerized communication. A new and more efficient system will require America's best ingenuity, consistent investment, and cooperation among the private and public sectors. While the short-terms costs could be $\$ 12$ a month for individual consumers, a modern grid will reduce long-term costs through increased efficiency and less wasted electricity. ${ }^{48}$

The President met resistance in his call for infrastructure investments during the fiscal cliff negotiations at the end of 2012. To be sure, any new spending is difficult to fund in the midst of a budget crisis. But modernizing our electricity grid is an investment in our future with benefits that will far exceed the costs. The President has supported a smart grid in the past, ${ }^{49}$ but needs to make it a higher priority in his second term to enable renewable energy to reach its full potential — and provide America a reliable electrical grid for the $21^{\text {st }}$ century and beyond.

\section{Climate Change Adaptation and Infrastructure Investment}

The physical, personal, and emotional devastation caused by Hurricane Sandy and the resulting cost estimates upward of $\$ 50$ billion are a stark reminder that large scale preparation for increasingly harsh weather conditions should be a top administration priority. ${ }^{50}$ In addition to the physical destruction to buildings, businesses and homes, Hurricane Sandy also demonstrated that our Nation's drinking water supply systems and

\footnotetext{
${ }^{46}$ Rick Merritt, Report: Smart grid could cost $\$ 476 B$, EE TIMES (May 24, 2011), http://www.eetimes. com/electronics-news/4216278/Report-Smart-grid-could-cost-476B.

${ }^{47}$ Estimating the Costs and Benefits of a SMart Grid, Electric Power Research Institute (Mar. 2011), http://ipu.msu.edu/programs/MIGrid2011/presentations/pdfs/Reference\%20Material\%20-\%20 Estimating\%20the\%20Costs\%20and\%20Benefits\%20of\%20the\%20Smart\%20Grid.pdf.

${ }^{48}$ Peter Behr, Smart Grid Costs Are Massive, but Benefits Will Be Larger, Industry Study Says, N.Y. TimeS, May 25, 2011, http://www.nytimes.com/cwire/2011/05/25/25climatewire-smart-grid-costs-are-massivebut-benefits-wi-48403.html.

${ }^{49}$ A Policy Framework for the $21^{\text {st }}$ Century Grid: Enabling Our Secure Energy Future, NATIONAL SCIENCE AND TEChNOlogy CounCil (June 2011), available at http://www.whitehouse.gov/ sites/default/files/microsites/ostp/nstc-smart-grid-june2011.pdf.

${ }^{50}$ POST-LANDFALl LOSS EstimateS FOR SuPERSTORM SANDY, supra note 14.
} 
wastewater treatment plants must be updated to protect public health. ${ }^{51}$ To withstand future weather events, we need to identify the most vulnerable areas, fortify threatened regions, and rebuild infrastructure.

We should continue to pursue climate change adaption efforts at all levels of government. EPA is preparing a climate change adaptation plan for the country, and an interagency adaptation task force is utilizing the expertise of 20 federal agencies to identify and develop recommendations for the President to improve the Nation's response and preparation to the impacts of climate change. ${ }^{52}$ Numerous states have designed projects to protect agriculture and wildlife. City governments such as Chicago and New York are assessing and planning for climate related damage due to increased heat and rising sea levels. ${ }^{53}$ Now we need to ensure effective inter-governmental coordination.

While the needs of a city or town in the Midwest are different than coastal cities, regional planning should be centralized to leverage best practices and new technology. An effective approach could identify a major research university in each of the six main regions of the continental United States to act as adaptation hubs. State and local governments, foundations, and private businesses could partner together with each university to identify and implement the most pressing adaptation needs for each region. The federal government would then be available to provide expertise, personnel, and financial support when severe storms occur.

For adaptation efforts to be successful, the President should urge Congress to preserve funding for the Federal Emergency Management Agency (FEMA), even if state and local programs and flood insurance receive more funding. ${ }^{54}$ Adequate funding for FEMA should be an area for bi-partisan support, since super-storms and other natural disasters do not choose their victims based on partisan affiliations. In addition, the President should include drinking water systems and wastewater treatment plants in his infrastructure proposals since they play a crucial role both in climate change adaptation and long-term environmental protection efforts.

III. Regulations to Protect Public Health and the Environment

The modern regulatory state has delivered substantial public health, environmental, worker safety, and consumer protection benefits, enhancing the quality of

\footnotetext{
${ }^{51}$ Michael Schwirtz, Sewage Flows After Storm Expose Flaws in System, N.Y. TimES, Nov. 29, 2012, at A1.

${ }^{52}$ U.S. Envt'l Protection Agency, Climate Change Impacts and Adapting to Change, http://www. epa.gov/climatechange/impacts-adaptation/ (last visited Jan. 5, 2013).

${ }^{53} I d$.

${ }^{54}$ Suzy Khimm, Obama cuts FEMA funding by 3 percent. Romney-Ryan cuts it by 40 percent. Or more. Or less., WASH. POST, Oct. 30, 2012, http://www.washingtonpost.com/blogs/wonkblog/wp/2012/10/30/obamacuts-fema-funding-by-3-percent-romney-ryan-cuts-it-by-40-percent-or-more-or-less/.
} 
life for all Americans. We should be proud of the high standards we demand of American products, our efforts to provide clean air and water for our communities, and our worker safety programs. We also should resist efforts to roll back regulatory protections and proposals that would make it difficult to enact new regulations that provide significant public health and environmental benefits. ${ }^{55}$

During the President's second term, EPA should continue to use the Clean Air Act to address climate change and conventional forms of air pollution. EPA also should enact new regulations to clarify the jurisdictional reach of the Clean Water Act, and federal agencies should develop a new regulatory regime to ensure that the powerful benefits of fracking do not come at the expense of public health and environmental harm to our communities.

\section{A. Clean Air Act Standards}

The Clean Air Act may be the most successful of our Nation's environmental laws. In 2010, EPA estimated that two of the National Ambient Air Quality Standards (for ozone and particulate matter) prevented 160,000 cases of premature mortality and 130,000 heart attacks. ${ }^{56}$ EPA estimates that costs associated with the 1990 Amendments to the Clean Air Act will total $\$ 65$ billion by 2020 - with benefits more than 30 times greater at $\$ 2$ trillion. $^{57}$

EPA's implementation of the Clean Air Act often involves substantial delays and legitimate debates about its requirements. When EPA faithfully administers the requirements of the Clean Air Act, however, its efforts deserve support from the President and from Congress and are entitled to deference from the courts. On at least three occasions during the President's first term, EPA came under attack in circumstances that were unwarranted. A sustainability agenda for the second term must include greater support for Clean Air Act regulatory programs.

First, EPA's efforts to regulate greenhouse gas emissions under the Clean Air Act led to vitriolic attacks of the Agency from Congress. ${ }^{58}$ The suggestion that EPA was acting in an unauthorized matter was curious given the Supreme Court's decision in

55 See David M. Uhlmann, The REINS Act: A Future without Environmental, Health, and Safety Protections, ACS BLOG (Feb. 25, 2011), http://www.acslaw.org/acsblog/all/professor-david-m.-uhlmann.

56 U.S. Envt'l Protection Agency, Benefits and Costs of CleAn AiR ACt Amendments of 1990, http://www.epa.gov/air/sect812/feb11/factsheet.pdf (last visited Jan. 5, 2013).

${ }^{57} I d$.

${ }^{58}$ See, e.g., Consumer Relief for Pain at the Pump Act, H.R. 1777, 111th Cong. $\$ 301$ (2011) (calling for the repeal of EPA climate change regulation under the Clean Air Act, NEPA, etc.); Energy Tax Prevention Act of 2011, H.R. 910, 111th Cong. (2011) (proposing to amend the Clean Air Act to prohibit the Administrator of the EPA from promulgating regulations or taking other actions to limit greenhouse gases in order to address climate change). 
Massachusetts v. EPA, ${ }^{59}$ which held that greenhouse gas emissions fall within the definition of pollutants under the Clean Air Act and must be regulated if the Agency finds that they endanger public health and welfare. The D.C. Circuit upheld EPA's action against attack by industry groups and several states, ${ }^{60}$ but the Supreme Court may hear further challenges to the rules and Congress may remain hostile.

The Justice Department should vigorously defend EPA's greenhouse gas regulations. In addition, the administration should continue to oppose efforts in Congress to repeal EPA's authority to regulate greenhouse gases under the Clean Air Act or to "defund" those efforts. The administration also should reject efforts to tie a carbon price signal to such repeal, since the Clean Air Act regulations address adverse health and environmental effects that may be reduced by a carbon price signal but are not likely to be eliminated by market forces alone.

Second, EPA's efforts to update its ozone regulations were blocked by the President $^{61}$ even though EPA demonstrated that the new regulations would provide substantial public health and environmental benefits. ${ }^{62}$ The President's statement cited the potential cost to state and local governments at a time when the economy already was weakened, as well as the fact that the standards were due for further revision in two years. ${ }^{63}$ Under the Clean Air Act, however, the Supreme Court has ruled that healthbased standards cannot take into account economic costs, so the revised standards should have gone forward in 2011. ${ }^{64}$ To protect public health and the environment, new ozone standards under the Clean Air Act should be a priority in 2013.

Third, EPA's regulations governing interstate pollution were struck down by the D.C. Circuit ${ }^{65}$ even though the regulations would provide public health benefits that far exceed their costs. EPA first issued the Clean Air Interstate Rule during 2005 to address the problem of pollution in "downwind" states that were adversely affected by emissions from power plants in utilities in "upwind" states. ${ }^{66}$ The D.C. Circuit struck down the 2005 rule but allowed it to stay in place until EPA issued a new rule, ${ }^{67}$ which occurred in 2011 when EPA promulgated the Cross-State Air Pollution Rule also known as the

\footnotetext{
59 549 U.S. 497 (2007).

${ }^{60}$ Coalition for Responsible Regulation, Inc. v. EPA, 684 F.3d 102 (D.C. Cir. 2012).

${ }^{61}$ Statement by the President on the Ozone National Ambient Air Quality Standards (Sept. 2, 2011), http://www.whitehouse.gov/the-press-office/2011/09/02/statement-president-ozone-nationalambient-air-quality-standards (requesting that the EPA delay implementation of the Ozone National Ambient Air Quality Standards until 2013).

${ }^{62}$ National Ambient Air Quality Standards for Ozone, 75 Fed. Reg. 2938 (Jan. 19, 2010) (to be codified at 40 C.F.R. pts. 50, 58).

${ }^{63}$ Statement by the President, supra note 60.

${ }^{64}$ Whitman v. Am. Trucking Ass'n, 531 U.S. 457 (U.S. 2001).

${ }^{65}$ EME Homer City Generation, L.P. v. EPA, 696 F.3d 7 (D.C. Cir. 2012).

${ }^{66}$ Clean Air Interstate Rule, 70 Fed. Reg. 25162 (final rule proposed May 12, 2005).

${ }^{67}$ Carolina v. EPA, 531 F.3d 896 (D.C. Cir. 2008).
} 
“Transport Rule." 68 The D.C. Circuit struck down the Transport Rule in 2012 based on claims that were not brought in the administrative process and an interpretation of the governing statute that is at odds with precedent and EPA's construction of the Act, which should have received Chevron deference. ${ }^{69}$

The Transport Rule would prevent tens of thousands of premature deaths every year by reducing harmful ozone and particulate pollution from upwind states. ${ }^{70}$ The Justice Department sought en banc review of the Transport Rule in October 2012. ${ }^{71}$ Efforts to uphold the rule are critical to implementation of the Clean Air Act's standards for ozone and particulate matter and therefore should remain a top priority for the administration. If the rule is not reinstated by the full D.C. Circuit, EPA should move as expeditiously as possible to promulgate a new version.

\section{B. Clean Water Act Jurisdiction}

The Clean Water Act marked its 40 ${ }^{\text {th }}$ anniversary during 2012 and deserves credit for dramatically improving water quality throughout the United States. The Clean Water Act has been effective in significant part because of its relative simplicity: all discharges of pollutants into waters of the United States are unlawful except where authorized by the Act, ${ }^{72}$ which most often involves obtaining a permit under the National Pollutant Discharge Elimination System. ${ }^{73}$

Enforcement of the Clean Water Act has been compromised in recent years, however, because of the Supreme Court's decision in Rapanos v. United States, ${ }^{74}$ which raised questions about the jurisdictional reach of the Clean Water Act. Before Rapanos, EPA and the Corps of Engineers jointly enforced regulations that ensured federal protection for most rivers and streams in the United States along with their adjacent wetlands. Rapanos held that the government's interpretation of the Clean Water Act exceeded what Congress had authorized but the Court failed to articulate a new standard, ${ }^{75}$ which has left Clean Water Act jurisprudence in shambles.

\footnotetext{
${ }^{68}$ Cross-State Air Pollution Rule, 76 Fed. Reg. 48,208 (final rule proposed Aug. 8, 2011).

${ }^{69}$ Chevron U.S.A., Inc. v. Natural Resources Defense Council, Inc., 467 U.S. 837 (1984) (when reviewing ambiguous statutory language, courts should defer to the agency's reasonable interpretation of the statute).

${ }^{70}$ Marla Cone, Smog standard rejected by Obama would save thousands of lives yearly, study finds, ENVIRONMENTAL HEALTH NEWS (July 20, 2012), http://www.environmentalhealthnews.org/ ehs/news/2012/smog-standard-rejected-by-obama-would-save-thousans-of-lives-each-year.

${ }^{71}$ EME Homer City Generation, L.P. v. EPA, No. 11-1302, Petition for Rehearing En Banc (D.C. Cir. Oct. 5, 2012).

7233 U.S.C. $\$ 1311(2006)$.

7333 U.S.C. $\$ 1342(2006)$.

74547 U.S. 715 (2006).

${ }^{75} \mathrm{Id}$.
} 
In Rapanos, Justice Scalia wrote for a plurality of the Court that jurisdiction under the Clean Water Act extends to all tributaries that have relatively permanent and consistent flow to navigable-in-fact waters and all wetlands that have surface water connection to those tributaries. ${ }^{76}$ A concurring opinion by Justice Kennedy argued that Clean Water Act jurisdiction extended to all tributaries with a significant nexus to water quality in navigable waters and to all adjacent wetlands that also have a significant nexus on water quality in navigable waters. ${ }^{77}$ But neither opinion was supported by five justices, so the Court created uncertainty about which tributaries and adjacent wetlands are entitled to federal protection under the Clean Water Act.

Since Rapanos, the federal courts of appeal have been divided on the question of which test applies in Clean Water Act enforcement actions. The Ninth and Eleventh Circuits have held that the Kennedy test applies; the First Circuit held that jurisdiction is present if either test is satisfied, noting as Justice Stevens did in dissent that a majority of the court would uphold jurisdiction if either test were met. ${ }^{78}$ The Supreme Court has refused to resolve the circuit split. ${ }^{79}$ Legislation has been introduced in Congress that would restore jurisdiction to its pre-Rapanos status but prospects for its passage are $\operatorname{dim}^{80}$ EPA and the Corps of Engineers have produced guidance explaining when jurisdiction is present but no new regulations have been issued. ${ }^{81}$

EPA and the Corps of Engineers should promulgate new regulations regarding the jurisdictional reach of the Clean Water Act early in the President's second term. The new regulations should adopt the position expressed by Justice Stevens in Rapanos, namely that jurisdiction should be present when either Justice Scalia's test or Justice Kennedy's test is met. Justice Scalia's test provides the benefit of a bright line rule, which aids effective enforcement, but it leaves out tributaries (and adjacent wetlands) that could have adverse effects on downstream waters. Justice Kennedy provides a more ecologically-based test, but would require expert testimony in every case about whether significant effects on water quality are present, which undermines effective enforcement. It is long past time for new regulations to be issued.

\footnotetext{
${ }^{76} \mathrm{Id}$. at 732-33 (relatively permanent waters) and 742 (hydrologically-connected wetlands).

${ }^{77} \mathrm{Id}$. at $779-80$.

${ }^{78}$ See, e.g. N. Cal. River Watch v. City of Healdsburg, 496 F.3d 993 (9th Cir. 2007); United States v. Robison, 505 F.3d 1208 (11th Cir. 2007); United States v. Johnson, 467 F.3d 56 (1st Cir. 2006).

${ }^{79}$ The Supreme Court denied petitions for certiorari in Robison, 555 U.S. 1045 (2008) and several other cases.

${ }^{80}$ The Clean Water Restoration Act, S. 787, 111th Cong. (2009).

81 U.S. Envtl Protection Agency, Clean Water ACt Definition of "Waters of the United STATES," http://water.epa.gov/lawsregs/guidance/wetlands/CWAwaters.cfm (last visited Jan. 5, 2013).
} 


\section{Regulating Fracking}

Hydraulic fracturing or "fracking" of natural gas is revolutionizing how we meet our energy needs in the United States. Natural gas from shale has surged from two percent of domestic production to 30 percent. $^{82}$ If the trend continues, fracking could provide a reliable domestic source of energy for the next century. ${ }^{83}$ The prospect of a new energy boom that would end our dependence on foreign oil and make America energy-independent within the decade is considered a win-win for national security and energy policy. It also is a tremendous economic opportunity for communities across America: robust fracking of natural gas is occurring in more than 30 states, ${ }^{84}$ compared to just five states (Texas, Alaska, California, North Dakota, and Oklahoma) that are responsible for more than 50 percent of domestic oil production. ${ }^{85}$

From an environmental standpoint, fracking may reduce greenhouse gas emissions, because natural gas results in far less carbon dioxide emissions than oil or coal. $^{86}$ In just the first two years of significant natural gas fracking activity, the United States has seen a decline in its carbon dioxide emission levels. ${ }^{87}$ At the same time, fracking poses a number of environmental risks, which include air pollution and increased greenhouse gas emissions from the venting of methane, groundwater pollution if fracking occurs near underground sources of drinking water, and potential surface water pollution if the vast quantities of water needed for fracking are not treated properly prior to disposal. ${ }^{88}$ Still other concerns involve excessive freshwater use, the potential for geological instability from fracking - and an increased risk of earthquakes - as well as the infrastructure demands on small communities and effects on neighboring properties. ${ }^{89}$

Given the potential significance of fracking to our economy and our future energy needs, it may come as a surprise to most Americans that federal regulatory authority is

82 Joe Nocera, Op-ed, How to Extract Gas Responsibly, N.Y. Times, Feb. 28, 2012, at A25.

${ }^{83}$ Natural gas: Shale of the Century, THE ECONOMIST, June 2012, http://www.economist.com/node/ 21556242.

${ }^{84}$ Natural Resources Defense Council, A Boom in Fracking Threatens Communities Across AMERICA (Apr. 2012), http://www.nrdc.org/naturesvoice/campaign1.asp.

${ }^{85}$ U.S. ENERGY INFORMATION ADMINISTRATION, Five STATES ACCOUNTED FOR ABOUT 56\% OF TOTAL U.S. CRUDE OIL PRODUCTION IN 2011, Mar. 14, 2012, http://www.eia.gov/todayinenergy/detail.cfm?id=5390 (last visited Jan. 5, 2013).

${ }^{86}$ From Coal To Gas: The Potential Risks And Rewards, NAT'L PUBLIC RADIO, (NPR radio broadcast July $15,2012)$, transcript available at http://www.npr.org/templates/transcript/transcript.php?storyId=15681 4490.

${ }^{87} I d$.

${ }^{88}$ Natural Gas Subcommittee of the Secretary of Energy Advisory Board, Safety of Gas SHALE DEVELOPMENT (2011) available at $\mathrm{http}: / / \mathrm{www}$. shalegas.energy.gov/resources/111811_final_report. pdf.

89 Dusty Horwitt and Alex Formuzis, USGS: Recent Earthquakes "Almost Certainly Manmade," ENVIRONMENTAL WORKING GROUP (Apr. 2012), http://www.ewg.org/analysis/usgs-recent-earthquakesalmost-certainly-manmade. 
limited for fracking. The federal government, of course, controls how fracking occurs on public lands. In addition, EPA can regulate methane venting from fracking, as well as the disposal of wastewater from fracking if it occurs in jurisdictional waters of the United States. But fracking itself was exempted from federal regulation in 2005 by what is known as the Halliburton exemption. ${ }^{90}$ As a result, regulation of the drilling activity is left to state and local governments, which produces a patchwork of laws that may not protect public health and the environment and imposes undue costs on industry by forcing national companies to comply with disparate state requirements. ${ }^{91}$

Fracking has become too central to our national energy policy to leave regulation of its health and environmental effects entirely to the states. The President should urge Congress to repeal the Halliburton exemption, so that we can move forward with fracking regulations that address both the benefits and the potential risks involved. As with other cooperative federalism programs, the federal government should set a "floor" for safeguards. Individual states would then implement the regulatory program with the option of going beyond federal requirements but could not offer less stringent protection. $^{92}$ The regulatory process should involve industry representatives, environmental leaders, and federal and state regulators. It should build on the work of the Department of Energy advisory board subcommittee that studied fracking in 2011, ${ }^{93}$ as well as the numerous studies that are occurring at universities. ${ }^{94}$ But we cannot regulate fracking the way we regulated deepwater drilling for oil, where we realized we had inadequate safeguards in place only after we experienced the worst accidental oil spill in world history. ${ }^{95}$ Indeed, with so many companies rushing to join the fracking boom, weak regulation could allow companies with poor safety programs to have accidents that jeopardize the entire industry.

If Congress fails to act, the President should use the authority he already has to protect our communities from the risks created by fracking. The Department of the Interior should continue to regulate fracking on public lands. EPA should update rules that prohibit the venting of methane from fracking and address any other harmful emissions that can be regulated under the Clean Air Act. EPA and the states should use

\footnotetext{
${ }^{90}$ Editorial, The Halliburton Loophole, N.Y. TIMES, Nov. 3, 2009, at A28.

${ }^{91}$ A BOOM IN FRACKING, supra note 84.

92 See Jody Freeman, Op-ed, The Wise Way to Regulate Hydraulic Fracking, N.Y. Times, July 6, 2012 at A23.

${ }^{93}$ SAFETy OF Gas Shale DeVElOPMENT, supra note 88.

${ }^{94}$ See, e.g. Jiang et al. Carnegie-Mellon Marcellus Greenhouse Gas Study: Life cycle greenhouse gas emissions of Marcellus shale gas, ENVIRON. ReS. LeTt. 6 (July-Sept. 2011); Osborn et al., THE DuKE UNIVERSITY STUDY: METHANE CONTAMINATION OF DRINKING WATER ACCOMPANYING GAS-WELL DRILLING AND HYDRAULIC FRACTURING (PNAS Early Edition, May 2011), available at http://www.pnas.org/ content/108/20/8172.full.

${ }^{95}$ Bradley Blackburn and Matt Gutman, BP Oil Spill Called Worst in U.S. History, as MMS Official Steps Down, ABC News (May 27, 2010), http://abcnews.go.com/WN/Media/bp-oil-leak-now-worst-historysurpassing-exxon/.
} 
their authorities under the Clean Water Act to protect water pollution, as well as under the Safe Drinking Water Act to protect drinking water supplies. State and local governments should address land use and infrastructure issues. But regulation must occur soon so that fracking does not result in environmental degradation.

\section{Conclusion}

The leadership opportunities for President Obama as he begins his second term are both numerous and daunting, and perhaps nowhere more so than for environmental issues. His legacy can be as the President who set America on a course for a sustainable future, recognizing our long-term obligation to mitigate global climate change and developing renewable energy and safe natural gas extraction that will secure our energy independence. He also can ensure that we take long-needed steps to better protect public health and the environment from near-term air pollution and water pollution problems. Some of these actions can be taken by the President alone; others must be done in cooperation with Congress and state and local governments, which will be difficult given the partisan rancor in Washington. But a sustainable future will depend upon the President's willingness to take his case directly to the American people and to make climate change, energy policy, and environmental protection top priorities in his second term. 